\title{
The Factors Involved in Bilateral Central Lymph Node Metastasis of Isthmus Papillary Thyroid Cancer
}

\author{
Keun-Ik Yi ${ }^{1}$, Soo-Geun Wang ${ }^{1}$, Byung-Joo Lee ${ }^{1}$, In Ju Kim², \\ Bo Hyun Kim², Sang Soo Kim ${ }^{2}$, and Jin-Choon Lee ${ }^{3}$ \\ ${ }^{I}$ Departments of Otorhinolaryngology-Head and Neck Surgery, ${ }^{2}$ Internal Medicine, Pusan National University Hospital, \\ Pusan National University School of Medicine, Busan; and ${ }^{3}$ Department of Otorhinolaryngology-Head and Neck Surgery, \\ Pusan National University Yangsan Hospital, Pusan National University School of Medicine, Yangsan, Korea
}

\author{
이근익 ${ }^{1} \cdot$ 왕수건 $^{1} \cdot$ 이병주 $^{1} \cdot$ 김인주 $^{2} \cdot$ 김보현 $^{2} \cdot$ 김상수 $^{2} \cdot$ 이진춘 $^{3}$ \\ 부산대학교 의과대학 부산대학교병원 이비인후과학교실, ${ }^{1}$ 내과학교실, ${ }^{2}$ \\ 부산대학교 의과대학 양산부산대학교병원 이비인후과학교실 ${ }^{3}$
}

갑상선 협부 유두상 암의 양측 중심 경부 림프절 전이에 관여하는 인자 분석

\author{
Received October 13, 2016 \\ Revised December 5, 2016 \\ Accepted December 13, 2016 \\ Address for correspondence \\ Jin-Choon Lee, MD, PhD \\ Department of Otorhinolaryngology- \\ Head and Neck Surgery, \\ Pusan National University \\ Yangsan Hospital, \\ Pusan National University \\ School of Medicine, \\ 20 Geumo-ro, Mulgeum-eup, \\ Yangsan 50612, Korea \\ Tel $+82-51-360-2132$ \\ Fax $+82-51-360-2930$ \\ E-mail1jc0209@hanmail.net
}

Background and Objectives The aims of this study were to evaluate the rate and risk factors involved in bilateral central lymph node metastasis in patients with papillary thyroid cancer (PTC) found in the isthmus and compared them to tumors located in other thyroid regions, using those findings to establish a surgical strategy for treating these tumors.

Subjects and Method We compared the clinical and pathological data of 48 patients with isthmic PTC and 141 patients with PTC found in other thyroid regions, all of whom underwent total thyroidectomy and bilateral central neck dissection.

Results The rates of bilateral central lymph node metastasis were higher in the isthmus group than in the non-isthmus group $(29.2 \%$ vs. $9.9 \% ; p=0.001)$. On multivariate analysis, the isthmic location of the tumor was an independent risk factor for bilateral central lymph node metastasis $(\mathrm{OR}=3.458 ; p=0.005)$. But the positional relationship between the tracheal midline and the nodule was not clear in lymph node metastasis in the isthmus group.

Conclusion Bilateral central neck dissection should be considered for isthmic PTC regardless of the relation between nodule and tracheal midline because of the high rate of bilateral central lymph node metastasis. Korean J Otorhinolaryngol-Head Neck Surg 2017;60(3):125-34

Key Words Lymphatic metastasis · Neck dissection · Papillary thyroid carcinoma · Thyroid gland.

\section{서 론}

갑상선 유두상암(papillary thyroid carcinoma)은 여포 세 포(follicular cell)에서 기원하는 갑상선 암종의 대부분을 차 지하는 조직 유형으로 일반적으로 예후가 매우 좋은 암이지 만 종종 림프절 전이를 일으키기 때문에 수술적 치료를 결정 하는 데 있어 림프절 전이의 양상을 명확히 아는 것이 중요하 다.) 중심 경부 림프절(central neck lymph node)은 갑상선 유 두상암의 전이가 가장 흔하게 일어나는 위치이며, ${ }^{2)}$ 이는 국소
재발률의 증가 및 생존율의 감소와 관련이 있다. ${ }^{34)}$ 현재까지 갑 상선 유두상암의 치료적 중심 경부 림프절 청소술(therapeutic central-compartment neck dissection)의 개념은 잘 정립되어 있으나, ${ }^{5)}$ 예방적 중심 경부 림프절 청소술(prophylactic central-compartment neck dissection)의 역할과 그 수술범위에 대한 것은 여전히 논란이 있다. ${ }^{6-9)}$

예방적 중심 경부 림프절 청소술 시행을 지지하는 입장에서 갑상선 유두상암은 림프절 전이의 유병률이 높으며,(10) 때문에 중심 경부 림프절에서의 미세 전이암 제거는 재발을 예방하고 
전체 생존율을 향상시킨다는 것이다. ${ }^{5,11,12)}$ 또한, 중심 경부 림 프절 재발로 인해 재수술을 시행할 경우에는 이에 따른 합병 증 발생률이 높아지며, ${ }^{13)}$ 병기 설정을 위하거나 수술 후 방사 성 요오드 치료(radioactive iodine therapy)의 필요 여부에 관 한 결정을 위해서는 림프절 상태에 대한 병리 보고서가 필요 하다는 점에서 예방적 중심 경부 림프절 청소술의 필요성이 제기되고 있다. ${ }^{14)}$ 하지만 통상적인 예방적 중심 경부 림프절 청 소술은 영구적인 부갑상선 기능 저하증(hypoparathyroidism) 및 반회후두신경(recurrent laryngeal nerve) 손상의 가능성 을 높인다. ${ }^{15,16)}$ American Thyroid Association의 최신 가이 드라인에 따르면 예방적 중심 경부 림프절 청소술은 진행암 (advanced primary tumor)인 경우(T3/T4), 임상적으로 외측 림프절 전이(lateral lymph node metastasis)가 의심되는 경 우(cN1b), 추가 치료 계획을 위한 정보 획득이 목적인 경우에 시행할 수 있으며, 종양의 크기가 작은 경우(T1/T2), 침윤이 없거나 임상적으로 림프절 전이 소견이 없는 경우 $(\mathrm{cN} 0)$ 에는 예방적 중심 경부 림프절 청소술을 시행하지 않을 수 있다. ${ }^{17)}$ 이 외에도 성별, 나이 등 중심 경부 림프절 전이에 관련이 있 다고 알려진 위험인자를 가진 환자에서도 예방적 중심 경부 림프절 청소술을 고려해야 한다. ${ }^{18)}$

모든 갑상선 유두상암의 대략 1 9\%까지는 갑상선 협부 (isthmus)에 위치해 있다. ${ }^{19-21)}$ 갑상선 협부는 기관(trachea)의 앞에 위치하고 있으며, 피대근(strap muscle), 근막(fascia) 및 피부(skin)와 인접하고 있어 갑상선 협부에서 발생한 유두상 암의 경우 다른 부위보다 국소 침범(local invasion)의 가능성 이 더 높은 것으로 알려져 있다. 22,23$)$ 그러나 갑상선 협부 유두 상암에서의 중심 경부 림프절 전이의 양상은 아직까지 충분 한 연구가 이루어지지 않았으며, ${ }^{14,21)}$ 명확한 치료 가이드라인 도 결정되지 않았다. ${ }^{20)} \mathrm{Song}$ 등 ${ }^{14)}$ 은 갑상선 협부에 발생한 유 두상암의 경우, 양측 중심 경부 림프절 전이 빈도가 높기 때문 에 중심 경부 림프절 청소술 시에 양측으로 시행할 것을 권유 하고 있다. 하지만 이미 언급한 바와 같이 양측 중심 경부 림프 절 청소술(bilateral central-compartment neck dissection)은 일측(unilateral)에 비해 수술 후 합병증의 발생률이 일반적으 로 높아진다. 따라서 갑상선 협부 유두상암의 치료에 있어 양측 및 일측 중심 경부 림프절 청소술을 결정할 수 있는 인 자들은 없는지, 특히 협부 내에서의 위치에 따른 차이는 없는 지에 대한 논의가 필요하다.

따라서 본 논문에서는 갑상선 협부에 발생한 유두상암에 서 중심 경부 림프절 전이의 빈도와 그와 관련된 인자에 대해 분석해 보고 아울러 중심 경부 림프절 청소술의 적절한 범위 에 대해 알아보고자 하였다.

\section{대상 및 방법}

본 저자들은 주요 결절이 갑상선 협부에 위치한 갑상선 유 두상암 환자 48 명을 대상으로 후향적 연구를 진행하였다. 이 들은 2011년 10월부터 2015년 12월까지 본원에서 갑상선 전절 제술(total thyroidectomy) 및 경부 림프절 청소술을 시행받 았다. 수술 전 갑상선 협부에 위치한 결절에 초음파 유도하 세 침흡인세포검사(ultrasonography-guided fine needle aspiration cytology)를 시행하여 Bethesda system상 class V 혹은 class VI의 결과가 나온 환자 중 수술 후 병리조직검사에서 다발성으로 협부 외 결절이 유두상암으로 진단된 경우는 연 구에서 배제하였다. 대조군은 2013년 2월부터 2015년 12월 까지 협부 외에 위치한 갑상선 유두상암에 대하여 갑상선 전 절제술 및 경부 림프절 청소술을 시행받은 141 명이었다. 이들 은 모두 단일 결절에서 유두상암으로 진단된 경우였다. 모든 환자에서 갑상선 전절제술 및 양측 중심 경부 림프절 청소술 을 시행하였고, 외측 경부 림프절 청소술은 선택적으로 시행 하였다. 협부 및 비협부(non-isthmus) 갑상선 유두상암 그룹 에서 환자 성별(sex), 나이(age), 종양크기(tumor size), 갑상선 외 침윤(extrathyroidal extension), TNM 병기(TNM stage), 신체질량지수(body mass index)를 비교하였다. 또한, 단변량 분석(univariate analysis)과 다변량 분석(multivariate analysis) 을 통해 종양 협부 위치를 포함하여 중심 경부 림프절 전이와 관련된 잠재적 위험요인을 분석하였다.

모든 환자에서 수술 전 신체검진 및 컴퓨터단층촬영(computed tomography), 초음파 검사를 포함한 영상검사를 시행 하였으며, 림프절 전이 유무를 평가하였다. 또한, 해당 갑상 선 결절 및 전이가 의심되는 림프절에 대하여 초음파 유도하 세침흡인세포검사를 시행하였고, 치료적 외측 경부 림프절 청 소술은 신체검진이나 영상검사에서 전이가 의심되거나 세침흡 인세포검사에서 확진되었을 때만 시행하였다. 임상적으로 외 측 경부 림프절 전이가 의심되지 않을 경우에는 예방적 외측 경부 림프절 청소술은 시행하지 않았다. 갑상선암의 다른 병 리 조직 유형을 가지거나 재발인 경우, 이전 경부수술이나 방 사선 치료를 받은 적이 있거나 갑상선 엽절제술(lobectomy) 이나 일측 중심 경부 림프절 청소술만 시행받은 환자는 대상 에서 제외하였다.

갑상선 협부 유두상암은 초음파 검사 소견을 바탕으로 기 관의 외측에 가상의 선을 그려 주요 결절의 중심이 양측 선 안쪽 범위에 위치하는 종양으로 정의하였다. 또한, 갑상선 협 부 내에서도 다양한 기준으로 결절 위치를 세분화하여 중심 경부 림프절 전이 유무를 분석하였는데 우선 기관의 중심부 를 이은 가상의 선을 그어 협부 결절이 그 가상선을 통과하는 
Thyroid Neoplasm, Papillary Thyroid Carcinoma, Thyroid Isthmus, Lymph Node Dissection, Lymphatic Metastasis I Yi KI, et al.

지 유무에 따라 각각 중심 협부 종양(median isthmic tumor), 비중심 협부 종양(non-median isthmic tumor)으로 분류하였 다(Fig. $1 \mathrm{~A}$ and B). 이어 기관 중심부와 결절 사이의 거리에 따른 전이 유무를 알아보기 위해 결절 중심과 기관의 중심 선 사이의 거리(Fig. $1 \mathrm{C}$ and $\mathrm{D}$; 기준 1 ) 및 기관의 중심선과 수직으로 가장 가까운 결절의 변연부까지의 거리(Fig. 1E and $\mathrm{F}$; 기준 2)를 측정하였다. 결절 중심과 기관 중심선 사이 의 거리는 기관 중심선을 기준으로 양측으로 멀어질수록 양 의 값을 가지는 것으로 하였고, 기관 중심선과 수직으로 가장 가까운 결절 변연부 사이의 거리는 결절이 중심선을 포함하 지 않으면 음의 값을, 중심선을 포함하면 양의 값을 가지는 것으로 하였다. 종양의 방향은 중심 협부 종양인 경우, 결절
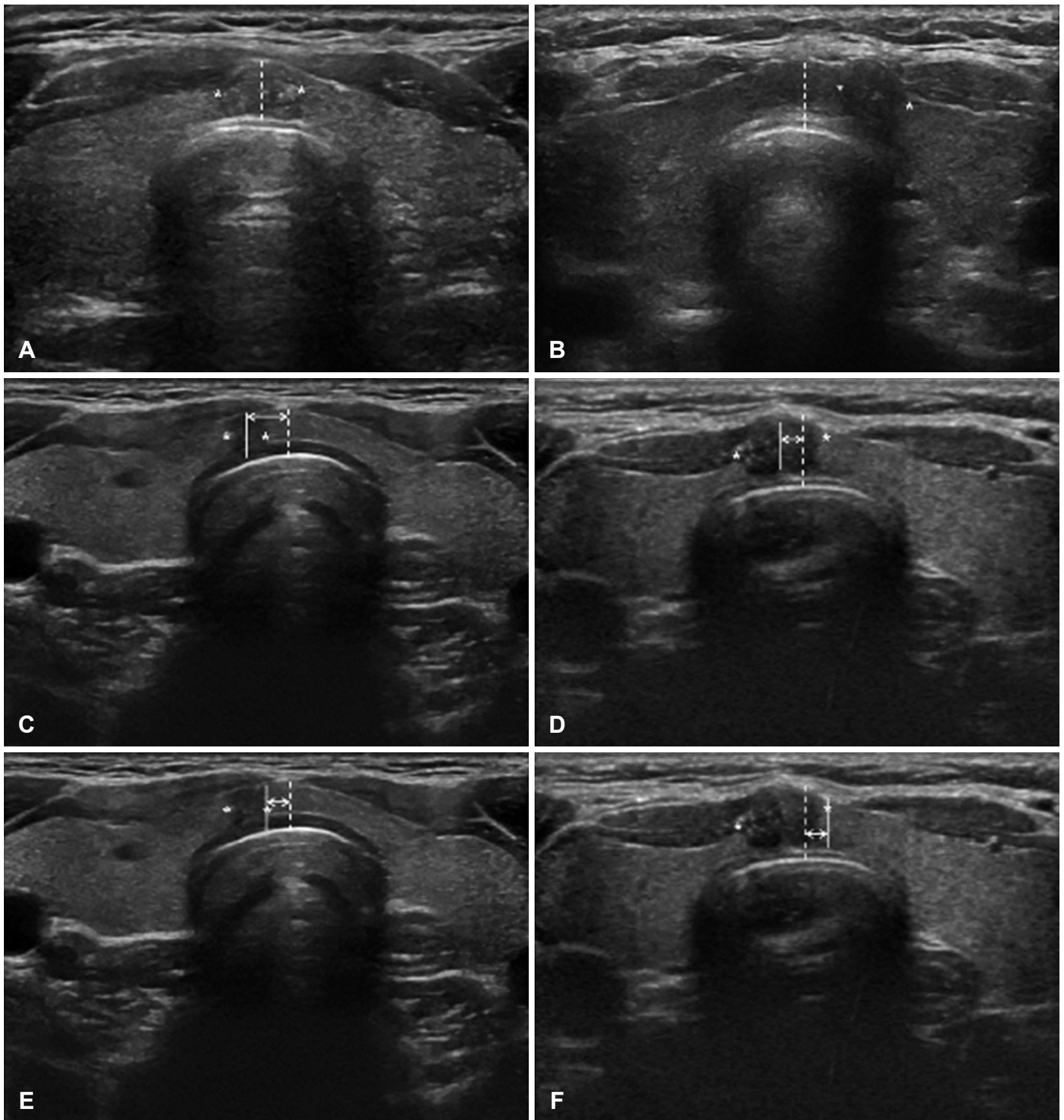

Fig. 1. Ultrasonographic axial view showing the location of the thyroid nodule. The margin of the nodule and the tracheal midline is marked with an asterisk and broken line, respectively. Median isthmic tumor. The nodule is beyond the tracheal midline (A). Non-median isthmic tumor. The nodule is located in thyroid isthmus but is not beyond the tracheal midline (B). The double arrow indicates the distance between the center of the nodule (full line) and the tracheal midline (criteria 1) (C and D). The double arrow indicates the distance to the nearest margin of the nodule (full line) on tracheal midline (criteria 2) (E and D). It has a negative value $(E)$ and positive value $(F)$ on the basis of the tracheal midline. 
의 중심이 위치한 방향으로 결정하였다.

통계적 분석 방법으로는 범주형 자료(categorical data)는 빈 도(frequency)와 백분율(percentage)을 이용하였고, 연속형 자

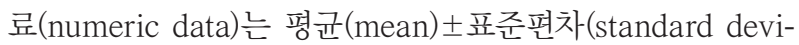
ation)를 이용하여 요약하였다. 그룹 간 차이를 분석하기 위 해 범주형 자료의 비교는 카이제곱 검정(chi-squared test) 및 Fisher 정확검정(Fisher's exact test)을, 연속형 자료의 비교는 독립 $\mathrm{t}$ 검정(independent $\mathrm{t}$-test)을 이용하였다. 중심 경부 림프 절 전이와 관련된 인자의 오즈비(odds ratio) 산출을 위해 다 중 로지스틱 회귀분석(multiple logistic regression analysis) 을 이용하여 분석하고 receiver operating characteristic(ROC) 커브 분석을 통해 중심 경부 림프절 전이 예측인자의 cut-off
값을 도출하였다. 통계 분석은 컴퓨터 통계분석 프로그램 (SPSS version 21.0; IBM Corp., Armonk, NY, USA)을 이 용하였으며, $p$ 값은 0.05 미만인 경우를 통계적으로 유의하다 고 정의하였다. Cut-off 값을 구하기 위한 ROC 커브 분석은 MedCalc(version 16.8; MedCalc, Ostend, Belgium)을 이용 하였다.

\section{결 과}

\section{임상병리학적 특징}

협부 및 비협부 환자군에 대한 임상적, 병리적 특징은 Table 1 에 기술하였다. 환자의 성별, 나이, 종양크기, 갑상선 외 침윤

Table 1. Study patients' baseline characteristics in isthmus and non-isthmus papillary thyroid carcinoma

\begin{tabular}{|c|c|c|c|}
\hline \multirow{2}{*}{ Variable } & \multicolumn{2}{|c|}{ Tumor location } & \multirow{2}{*}{$p$ value } \\
\hline & Isthmus ( $n=48)$ no. of patients (\%) & Non-isthmus ( $n=141)$ no. of patients (\%) & \\
\hline \multicolumn{4}{|l|}{ Sex } \\
\hline Male & $7(14.6)$ & $21(14.9)$ & 0.958 \\
\hline Female & $41(85.4)$ & $120(85.1)$ & \\
\hline Age (yrs) & $45.40 \pm 11.14$ & $47.82 \pm 13.72$ & 0.224 \\
\hline$<45$ & $24(50.0)$ & $76(39.7)$ & 0.213 \\
\hline$\geq 45$ & $24(50.0)$ & $85(60.3)$ & \\
\hline Tumor size $(\mathrm{cm})$ & $0.89 \pm 0.47$ & $0.97 \pm 0.62$ & 0.383 \\
\hline$\leq 1$ & $33(68.7)$ & $89(63.1)$ & 0.481 \\
\hline$>1$ & $15(31.3)$ & $52(36.9)$ & \\
\hline \multicolumn{4}{|l|}{ Extrathyroidal extension } \\
\hline Yes & $29(60.4)$ & $64(45.4)$ & 0.072 \\
\hline No & $19(39.6)$ & $77(54.6)$ & \\
\hline \multicolumn{4}{|l|}{ T classification } \\
\hline Tla & $15(31.3)$ & $64(45.4)$ & 0.201 \\
\hline Tlb & $3(6.3)$ & $10(7.1)$ & \\
\hline $\mathrm{T} 2$ & 0 & $4(2.8)$ & \\
\hline T3 & $30(62.5)$ & $62(44.0)$ & \\
\hline $\mathrm{T} 4 \mathrm{a}$ & 0 & $1(0.7)$ & \\
\hline \multicolumn{4}{|l|}{ N classificaion } \\
\hline NO & $13(27.1)$ & $23(16.3)$ & 0.251 \\
\hline $\mathrm{Nla}$ & $32(66.7)$ & $106(75.2)$ & \\
\hline $\mathrm{N} 1 \mathrm{~b}$ & $3(6.3)$ & $12(8.5)$ & \\
\hline \multicolumn{4}{|l|}{ TNM stage, AJCC } \\
\hline I & $28(58.3)$ & $68(48.2)$ & 0.431 \\
\hline$\|$ & 0 & 0 & \\
\hline III & $17(35.4)$ & $65(46.1)$ & \\
\hline IVa & $3(6.3)$ & $8(5.7)$ & \\
\hline BMI & $23.37 \pm 3.68$ & $23.88 \pm 3.82$ & 0.426 \\
\hline$<25$ & $34(70.8)$ & $94(66.7)$ & 0.594 \\
\hline$\geq 25$ & $14(29.2)$ & 47 (33.3) & \\
\hline Total harvest central LN & $10.44 \pm 4.82$ & $11.23 \pm 6.51$ & 0.438 \\
\hline No. of central LN metastasis & $2.94 \pm 2.48$ & $2.75 \pm 1.95$ & 0.596 \\
\hline
\end{tabular}


Thyroid Neoplasm, Papillary Thyroid Carcinoma, Thyroid Isthmus, Lymph Node Dissection, Lymphatic Metastasis I Yi KI, et al.

Table 2. Subsites of lymph node metastasis in isthmic and non-isthmic papillary thyroid carcinoma

\begin{tabular}{lccc}
\hline \multicolumn{1}{c}{ Subgroup of lymph nodes } & Isthmus cancer $(\mathrm{n}=48)$ & Non-isthmus cancer $(\mathrm{n}=141)$ & $\mathrm{p}$ value \\
\hline Ipsilateral paratracheal lymph node & $32(66.7)$ & $113(80.1)$ & 0.056 \\
Bilateral paratracheal lymph node & $14(29.2)$ & $14(9.9)$ & $0.001^{*}$ \\
Contralateral paratracheal lymph node & $17(35.4)$ & $18(12.8)$ & $0.000^{*}$ \\
Unilateral paratracheal lymph node & $21(43.8)$ & $103(73.0)$ & $0.000^{*}$ \\
Only contralateral paratracheal lymph node & $3(6.3)$ & $4(2.8)$ & 0.373 \\
Only ipsilateral paratracheal lymph node & $18(37.5)$ & $99(70.2)$ & $0.000^{*}$ \\
Unilateral lateral lymph node & $1(2.1)$ & $12(8.5)$ & 0.190 \\
Bilateral lateral lymph node & $2(4.2)$ & 0 & 0.063 \\
\hline
\end{tabular}

*indicates statistical significance $(p<0.05)$

Table 3. Univariate analysis of clinicopathological factors associated with bilateral central lymph node metastasis

\begin{tabular}{|c|c|c|c|}
\hline \multirow{2}{*}{ Variable } & \multicolumn{2}{|c|}{$\begin{array}{c}\text { Bilateral central lymph } \\
\text { node metastasis }\end{array}$} & \multirow{2}{*}{$p$ value } \\
\hline & $\begin{array}{l}\text { Absent } \\
(\mathrm{n}=161)\end{array}$ & $\begin{array}{c}\text { Present } \\
(n=28)\end{array}$ & \\
\hline \multicolumn{4}{|l|}{ Tumor location } \\
\hline Isthmus & $34(21.1)$ & $14(50.0)$ & $0.001^{*}$ \\
\hline Non-isthmus & $127(78.9)$ & $14(50.0)$ & \\
\hline \multicolumn{4}{|l|}{ Sex } \\
\hline Male & $22(13.7)$ & $6(21.4)$ & 0.385 \\
\hline Female & $139(86.3)$ & $22(78.6)$ & \\
\hline \multicolumn{4}{|l|}{ Age (years) } \\
\hline$<45$ & $63(39.1)$ & $17(60.7)$ & $0.033^{*}$ \\
\hline$\geq 45$ & $98(60.9)$ & $11(39.3)$ & \\
\hline \multicolumn{4}{|l|}{ Tumor size $(\mathrm{cm})$} \\
\hline$\leq 1$ & $106(65.8)$ & $16(57.1)$ & 0.375 \\
\hline$>1$ & $55(34.2)$ & $12(42.9)$ & \\
\hline \multicolumn{4}{|c|}{ Extrathyroidal extension } \\
\hline Yes & $76(47.2)$ & $17(60.7)$ & 0.187 \\
\hline No & $85(52.8)$ & $11(39.3)$ & \\
\hline \multicolumn{4}{|l|}{ BMI } \\
\hline$<25$ & $111(68.9)$ & $17(60.7)$ & 0.390 \\
\hline$\geq 25$ & $50(31.1)$ & $11(39.3)$ & \\
\hline
\end{tabular}

*indicates statistical significance $(p<0.05)$. BMl: body mass index

유무, TNM 병기, 신체질량지수에서 두 군 간 차이는 보이지 않았다. 절제한 림프절 개수 및 전이된 림프절 개수에서도 차 이는 없었다. 갑상선 외 침윤 소견은 협부 유두상암의 $60.4 \%$ (29 case)에서 존재한 반면 비협부 유두상암에서는 45.4\%(64 case)에서 존재하였으나 통계적으로 의미는 없었다 $(p=0.072)$.

협부군과 비협부군의 중심 경부 림프절 전이 비율은 의미 있는 차이는 없었다(72.9\% vs. 83.0\%; $p=0.129)$. 림프절 전이 양상을 세분화하여 살펴보았을 때(Table 2), 동측 기관주위 림프절(ipsilateral paratracheal lymph node) 전이에서 두 군 간 차이는 없었다 $(66.7 \%$ vs. $80.1 \% ; p=0.056)$. 양측 기관주위 림프절(bilateral paratracheal lymph node) 전이는 협부 $29.2 \%$, 비협부 $9.9 \%$ 로 의미 있는 차이를 보였으며 $(p=0.001)$,
반대측 기관주위 림프절(contralateral paratracheal lymph node) 전이의 경우에도 협부(35.4\%)에서 비협부(12.8\%)보다 전이율이 높았다 $(p=0.000)$.

치료적 외측 경부 림프절 청소술은 협부 그룹에서 $8.3 \%(4$ case), 비협부 그룹에서는 9.9\%(14 case)에서 시행하였다. 외측 림프절 전이율은 두 군 간 차이가 없었으나 $6.3 \%$ vs. $8.5 \%$; $p=0.764)$, 양측 외측 림프절 전이의 경우는 비협부 유두상암 에서 없었으나 협부 유두상암에서는 $2 \mathrm{case}(4.2 \%)$ 가 있었다 ( $p=0.063)$. 협부암군에서 1 case는 level III에서 수술 전 초음 파 검사상 경계성(borderline) 전이 소견이 관찰되어 수술 시 에 의심되는 림프절만 선택적으로 절제하여 동결절편검사를 시행하였다. 그 결과 전이가 아닌 것으로 확인되어 추가적인 외측 경부 림프절 청소술은 시행하지 않았다. 비협부 그룹의 1 case에서도 Level IV에 전이가 의심되는 소견이 있었으나 동 결절편검사 후 전이가 확인이 되지 않아 추가적인 외측 경부 림프절 청소술은 시행하지 않았다. 또 다른 1 case에서는 외 부 병원에서 Level II의 림프절에 대한 세침흡인세포검사상 전이가 확인되어 외측 경부 림프절 절제술을 시행하였으나 최종 병리조직검사에서 전이가 없음이 확인되었다.

\section{양측 중심 경부 림프절 전이}

단변량 분석에 따르면 양측 중심 경부 림프절 전이는 협부 에 위치한 결절 $(p=0.001), 45$ 세 미만 $(p=0.033)$ 과 유의한 관련 성이 있었으며, 그 외 $1 \mathrm{~cm}$ 초과 종양크기 $(p=0.375)$, 남성 $(p=$ $0.385)$, 갑상선 외 침윤 $(p=0.187)$ 소견은 통계적으로 의미가 없었다(Table 3). 다중 로지스틱 회귀분석을 시행하였을 때 종양의 위치(isthmus vs. non-isthmus)에 따른 양측 중심 경 부 림프절 전이 발생 오즈는 3.458 $(p=0.005)$ 로 협부에 위치한 결절일 경우에 양측 중심 경부 림프절 전이 발생 오즈가 높은 것으로 나타났다(Table 4).

\section{협부 종양 위치에 따른 비교 분석}

갑상선 협부 유두상암 환자 48명만을 대상으로 종양의 위 
치 외에 중심 경부 림프절 전이에 관여하는 인자에 대한 단 변량 및 다변량 분석을 시행하였다. 양측 및 반대측 중심 경 부 림프절 전이에는 성별 $(p=0.400)$, 나이 $(p=0.057)$, 종양크기 $(p=0.738)$, 갑상선 외 침윤 유무 $(p=0.725)$, 신체질량지수 $(p=0.954)$ 모두 통계적으로 유의한 관련성을 보이지 않았다.
협부 종양 내에서도 그 위치를 세분화했을 때 림프절 전이 비율에 차이가 있는지에 대한 분석을 시행하였다. 협부 종양 의 위치를 기관 중심선과의 거리를 기준으로 ROC 커브 분석 을 이용하여 민감도(sensitivity) 및 특이도(specificity)를 종합 적으로 고려한 가장 의미가 있는 cut-off 값을 도출하고자 하

Table 4. Multivariate logistic regression for bilateral central lymph node metastasis

\begin{tabular}{|c|c|c|c|c|c|c|}
\hline \multirow{2}{*}{ Variable } & \multirow{2}{*}{$\beta$} & \multirow{2}{*}{ SE } & \multirow{2}{*}{$p$ value } & \multirow{2}{*}{$\operatorname{Exp}(\beta)$} & \multicolumn{2}{|c|}{$95 \% \mathrm{Cl}$} \\
\hline & & & & & Lower & Upper \\
\hline Tumor location (isthmus) & 1.241 & 0.445 & 0.005 & $3.458^{*}$ & 1.445 & 8.275 \\
\hline Sex (male) & 0.472 & 0.554 & 0.394 & 1.603 & 0.542 & 4.744 \\
\hline Age ( $\geq 45$ yrs $)$ & -0.876 & 0.447 & 0.050 & 0.417 & 0.173 & 1.001 \\
\hline Tumor size $(>1 \mathrm{~cm})$ & 0.123 & 0.478 & 0.797 & 1.131 & 0.443 & 2.888 \\
\hline Extrathyroidal extension (yes) & 0.457 & 0.477 & 0.339 & 1.579 & 0.619 & 4.025 \\
\hline $\mathrm{BMI}(\geq 25)$ & 0.364 & 0.457 & 0.426 & 1.439 & 0.587 & 3.527 \\
\hline
\end{tabular}

*indicates statistical significance $(p<0.05)$. Exp $(\beta)$ : odds ratio. Cl: confidence interval, BMl: body mass index

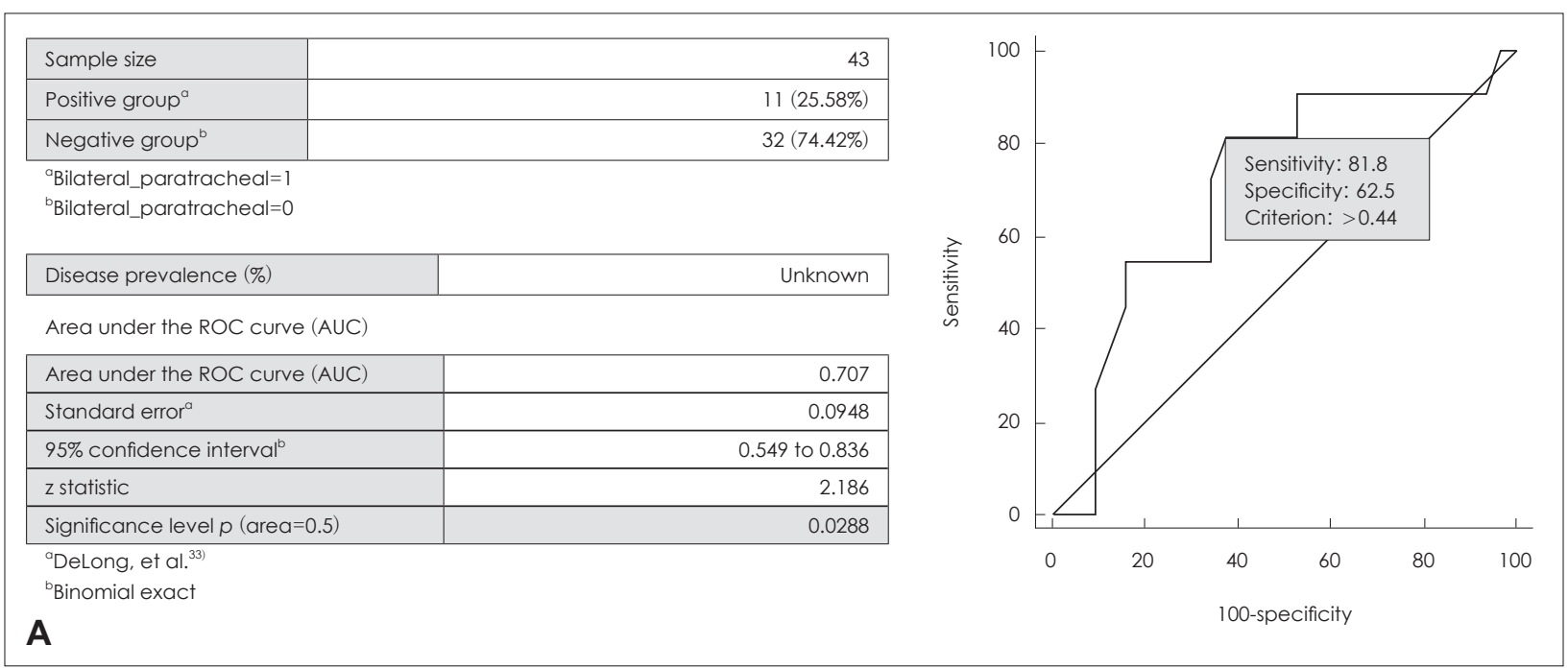

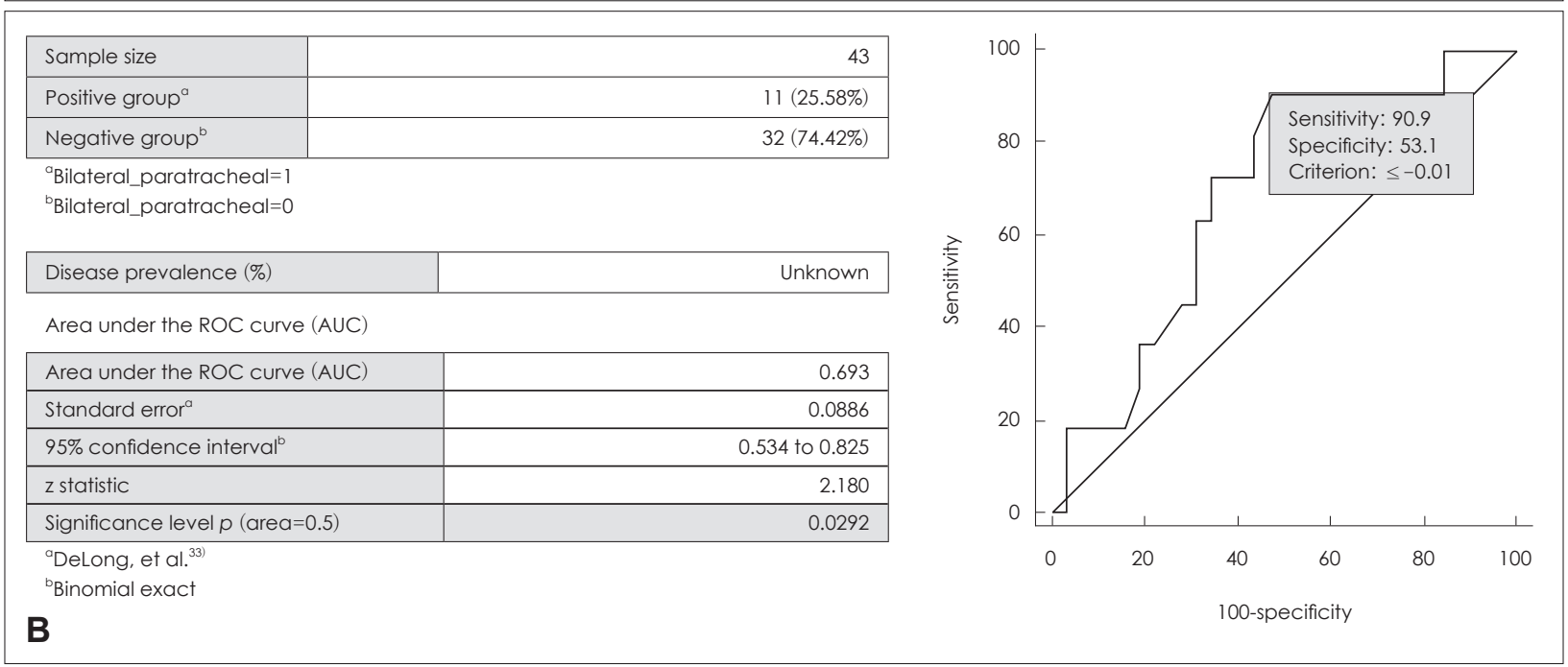

Fig. 2. ROC curve analysis to derive the cut-off value related to the bilateral central lymph node metastasis using criteria 1 (A) and criteria 2 (B). ROC: receiver operating characteristic. 
Thyroid Neoplasm, Papillary Thyroid Carcinoma, Thyroid Isthmus, Lymph Node Dissection, Lymphatic Metastasis I Yi KI, et al.

Table 5. Univariate analysis of factors related in length associated with bilateral central lymph node metastasis in isthmic tumor

\begin{tabular}{|c|c|c|c|}
\hline \multirow{2}{*}{ Variable } & \multicolumn{2}{|c|}{ Bilateral central lymph node metastasis } & \multirow{2}{*}{$p$ value } \\
\hline & Absent & Present & \\
\hline $\begin{array}{l}\text { Distance from midline of trachea to center } \\
\text { of nodule (criteria } 1, n=43 \text { ) }\end{array}$ & $0.40 \pm 0.27$ & $0.55 \pm 0.23$ & 0.095, t-test \\
\hline$>0.44$ & $12(37.5 \%)$ & $9(81.8 \%)$ & $0.011^{*}$, chi-square test \\
\hline$\leq 0.44$ & $20(62.5 \%)$ & $2(18.2 \%)$ & \\
\hline $\begin{array}{l}\text { Distance from midline of trachea to closest margin } \\
\text { of nodule (criteria } 2, n=43 \text { ) }\end{array}$ & $0.02 \pm 0.35$ & $-0.21 \pm 0.27$ & 0.053 , t-test \\
\hline$\leq-0.01$ & $15(46.9 \%)$ & $10(90.9 \%)$ & $0.014^{*}$, chi-square test \\
\hline$>-0.01$ & $17(53.1 \%)$ & $1(9.1 \%)$ & \\
\hline \multicolumn{4}{|l|}{ Excess of tracheal midline $(n=48)$} \\
\hline Yes (median) & $19(55.9 \%)$ & $2(14.3 \%)$ & $0.008^{*}$, chi-square test \\
\hline No (non-median) & $15(44.1 \%)$ & $12(85.7 \%)$ & \\
\hline
\end{tabular}

*indicates statistical significance $(p<0.05)$

였다. 우선, 앞서 설명한 기준 1을 이용하여 측정한 거리에서 양측 중심 경부 림프절 전이 여부와 관련된 기준 값은 0.44 $\mathrm{cm}(p=0.029)$ 였고, 기준 2 를 이용하여 측정한 거리로 $\mathrm{ROC}$ 커브 분석을 시행하였을 때 그 값은 $-0.01 \mathrm{~cm}(p=0.029)$ 였다

(Fig. 2).

협부 종양을 중심 협부 종양과 비중심 협부 종양 두 그룹으 로 나누어 양측 중심 경부 림프절 전이 유무를 비교하였고, 또 한 앞서 측정한 거리 값을 기준으로도 양측 중심 경부 림프 절 전이에 대한 단변량 분석을 시행하였다(Table 5). 양측 중심 경부 림프절 전이가 있는 그룹과 전이가 없는 그룹에서 기준 1 에 따른 거리는 각각 $0.55 \pm 0.23 \mathrm{~cm}, 0.40 \pm 0.27 \mathrm{~cm}$ 로 의미 가 없었으며 $(p=0.095)$, 기준 2 에 따른 거리는 각각 $-0.21 \pm$ $0.27 \mathrm{~cm}, 0.02 \pm 0.35 \mathrm{~cm}$ 로 역시 의미가 없었다 $(p=0.053)$. 하지 만 기준 1 과 기준 2에서 $\mathrm{ROC}$ 커브 분석으로 도출하였던 cutoff 값을 기준으로 두 군으로 나누어 분석했을 때, 기준 $1(p=$ $0.011)$ 과 기준 2( $p=0.014)$ 모두 차이가 있었다. 그리고 중심 협 부 종양과 비중심 협부 종양으로 나누어 분석한 결과도 양측 중심 경부 림프절 전이 여부에서 의미 있는 차이를 보였다 $(p=$ 0.008). 중심 협부 종양은 21 case, 비중심 협부 종양은 27 case 였으며 두 군 간에는 성별 $(p=0.959)$, 나이 $(p=0.771)$, 종양크기 $(p=0.126)$, 갑상선 외 침범 $(p=0.683)$ 에서 통계적으로 유의한 차이가 없었다.

\section{고 찰}

현재까지 갑상선 분화암의 치료에 대한 전반적인 가이드라 인은 다음과 같다. 단일(isolated) 결절로 일측(unilateral)의 갑 상선내(intrathyroidal)에 있는 $1 \mathrm{~cm}$ 이하의 미세암(microcarcinoma)를 가진 45세 미만의 환자에서는 임상적으로 경부 림 프절 전이가 의심되지 않는다면 갑상선 엽절제술(lobectomy)
로도 충분한 치료 결과를 얻을 수 있다. 반면, 갑상선 전절제 술은 15 세 미만 혹은 45 세 이상의 환자에게서 갑상선암 가족 력이 있고 두경부에 방사선 조사력이 있으며, 전이 소견이 보 이고 반대측 갑상선 결절이 관찰되고 피막 침범소견이 있는 거 대암(macrocarcinoma)인 경우에서 고려할 수 있다. ${ }^{24,25)}$ 하지 만 협부에 위치한 갑상선암에 대한 연구는 현재까지 충분히 논 의되지 않았다. ${ }^{17,26)}$

갑선선암은 협부에서는 비교적 드물게 발견된다. 갑상선 협 부는 두개의 외측 엽을 연결하며, 사람의 67 97\%까지 발견 된다. ${ }^{27-30)}$ 보통 두 번째에서 네 번째 기관륜의 앞쪽에 위치해 있고 드물게는 첫 번째 및 여섯 번째 기관륜까지 발견된다. 크기는 나이 및 성별에 따라 차이가 있으며, 여러 논문에 의 하면 갑상선 협부의 길이는 $11 ~ 20 \mathrm{~mm}$, 너비는 $10.5 \sim 20 \mathrm{~mm}$ 이며, 두께는 2 6 mm로 보고하고 있다. ${ }^{31,32)}$ 갑상선 협부는 피대근, 근막 및 피부와 인접하고 있어 다른 부위보다 갑상선 유두상암 국소 침범의 가능성이 더 높은 것으로 알려져 있 다. ${ }^{19,21-23)}$ Lee 등 ${ }^{19}$ 은 협부에 위치한 갑상선암 그룹이 비협부 갑상선암 그룹에 비해 피막침윤(capsular invasion) 및 다발 성(multifocality) 비율이 더 높기 때문에 협부에 위치한 갑상 선 유두상암의 수술적 치료 시 갑상선 엽절제술 또는 협부절 제술(isthmectomy)보다는 갑상선 전절제술을 더 고려해야 한다고 하였다(capsular invasion, $70.2 \%$ vs. $60.8 \% ; p=0.008$; multifocality, $48.6 \%$ vs. $39.8 \% ; p=0.006)$. 또한, Goldfarb 등 ${ }^{20)}$ 은 협부 갑상선암이 전체 그룹과 비교하여 높은 비율로 다발성 $(p=0.08)$, 피막침윤 $(p=0.09)$, 림프절 전이 $(p=0.09)$ 소 견을 보였으며, 따라서 협부 갑상선 유두상암의 수술 시 갑 상선 전절제술 및 중심 경부 림프절 청소술이 필요하다고 하 였다. 하지만 이들 연구에서는 모두 중심 경부 림프절 청소술 의 범위에 대한 합의는 이루어지지 않았다. 특히 대상 환자군 이 갑상선 전절제술 및 일측 중심 경부 림프절 청소술을 시 
행받아 양측 중심 경부 림프절 전이에 대한 평가가 빠져 있다.

갑상선의 림프절은 혈관과 평행하게 주행하며, 아래쪽으로 는 기관주위 림프절, 기관전 림프절, 쇄골상 림프절로 빠져나 간다. 갑상선 유두상암의 경우 전이는 중심 경부 림프절로 이 루어지는 경우가 많으며 그중 기관주위 림프절로의 전이가 가장 흔하다고 보고되었다. ${ }^{1)}$ 림프절 전이는 또 다른 림프절 전 이의 위험인자로 알려져 있으며,2) 따라서 갑상선 유두상암에 있어 림프절 전이 양상에 대한 연구와 수술 시 림프절 청소 술의 범위에 대한 논의가 필요하다. Song 등 ${ }^{14)}$ 은 반대측 기 관주위 림프절을 포함한 양측 중심 경부 림프절 청소술을 시 행한 환자만을 대상으로 한 연구에서 협부 갑상선 유두상암 의 중심 경부 림프절 전이율은 $71.1 \%$ 로 비협부암보다 확연히 더 높았다고 하였다 $(40.3 \%, p<0.001)$. 또한, 일측과 양측 중심 림프절 모두에서 조직학적 전이의 비율은 비협부 갑상선 유 두상암에서보다 협부에서 더 높았다. 양측 중심 림프절 전이 는 협부 종양의 중앙 위치 때문인 것으로 보여지며, 이것이 양 측 중심 경부 림프절로 퍼질 수 있도록 하므로 협부에 위치 한 갑상선암의 수술적 치료 시 양측 중심 경부 림프절 청소술 을 해야 하는 근거로 제시하였다.

본 연구에서의 협부 갑상선 유두상의 중심 경부 림프절 전 이 비율은 $72.9 \%$ 로 이전 연구와 비슷한 양상을 보였다. 하지 만 비협부 갑상선 유두상암의 중심 경부 림프절 전이 비율은 $83.0 \%$ 로 협부에 위치한 그룹과 차이가 없었으며 $(p=0.129)$, 타 연구의 비협부 갑상선암 림프절 전이보다 높은 결과를 보 였다. 이것은 본 연구의 대조군이 갑상선 전절제술 및 양측 중심 경부 림프절 청소술을 시행한 환자군만을 대상으로 시 행하였으며, 본원에서 일측 혹은 양측 중심 경부 림프절 청 소술의 범위를 결정할 때 수술 시 동측의 기관주위 림프절을 제거 후 동결절편검사를 통하여 림프절 전이가 확인된 경우 에 반대측의 기관주위 림프절을 추가로 제거한 경우가 많았 기 때문으로 생각된다. 따라서 기존에 알려진 일반적인 유두 상암의 림프절 전이 비율보다 본 연구에서 림프절 전이 비율 이 더 높게 나온 것으로 볼 수 있고 이것은 표본선택편의(selection bias)로 발생한 제한점이라고 할 수 있다. 하지만 이처 럼 본 연구에서 협부 및 비협부 갑상선 유두상암 그룹에서 중 심 경부 림프절 전이 비율이 비슷한 양상을 보였더라도 양측 림프절 전이 비율은 협부 그룹에서 통계적으로 유의하게 높 은 결과를 보였다(29.2\% vs. $9.9 \% ; p=0.001)$. 다중 로지스틱 회귀분석을 통하여 다른 인자의 편향 가능성을 배제한 후에 도 협부 위치는 중심 림프절 전이에 독립적인 위험인자인 것 으로 나타났다(OR=3.458; $p=0.005)$.

하지만 양측 경부 림프절 청소술의 일상적인 시행은 합병증 발생률의 상승을 동반할 수 있다. 협부에 위치한 갑상선암에
서 위치 외 중심 경부 림프절 전이에 영향을 주는 다른 요인 이 있다면 모든 협부 갑상선 유두상암 치료에서 양측 경부 림 프절 청소술을 시행할 필요는 없을 것이고 불필요한 합병증 상승을 피할 수 있을 것이다. 따라서 본 연구에서는 협부에 위치한 갑상선암 그룹 내에서 성별, 나이, 종양크기, 갑상선 외 침윤, 신체질량지수, 그리고 다발성에서 양측 중심 경부 림프 절 전이와 통계적으로 유의한 관계가 있는지에 대한 평가를 시행하였다. 그 결과는 종양의 위치를 제외하고 통계적으로 유의한 다른 요인은 없었으며 종양이 협부에 위치한 것 자체 가 강력한 독립 인자가 되었다.

또한 종양의 위치가 중심 경부 림프절 전이에 관련된 인자 라면 그 위치 안에서 다시 림프절 전이에 영향을 주는 기준 은 무엇인지 알아보기 위해 몇 가지 기준을 설정하였다. 먼저, 기관 중심선과 종양 중심까지의 거리를 기준(기준 1)으로 시 행한 ROC 커브 분석에서 구한 cut-off 값은 $0.44 \mathrm{~cm}$ 였으며 이 값으로 나눈 두 군은 단변량 분석에서 의미 있는 차이가 있는 것으로 나타났다 $(p=0.011)$. 결절 중심까지의 거리는 결 절의 위치에 대한 평가는 할 수 있지만 결절 크기에 따른 중 앙선 침범 유무는 반영이 되지 않기 때문에 기관 중심선과 가 장 가까운 결절 변연부까지의 거리도 측정해 보았는데(기준 $2)$, cut-off 값은 -0.01 로 이 역시 의미 있는 차이를 보였다 $(p=$ 0.014). 마지막으로 중심 협부 종양과 비중심 협부 종양으로 나누어 분석한 결과도 의미 있는 차이를 보였다. 특히, 기준 2 로 얻은 값은 기관의 중심선과 일치하여 같은 환자군을 포함 하였다. 하지만 기관의 중심부와 가깝거나 더 나아가 중심부 를 지나쳐 반대편 엽으로 침범되어 있는 결절일수록 양측 중 심 경부 림프절 전이가 잘 일어날 것이라는 우리의 예상과는 반대로 기관 중심선과 결절 중심부위까지의 거리가 $0.44 \mathrm{~cm}$ 이상인 경우, 그리고 비중심 협부 종양인 경우에서 양측 중 심 경부 림프절 전이율이 더 높았다. 비록 통계적으로 의미 있는 결과를 보였다고 하더라도 본 연구에 포함된 협부 유두 상암 환자는 총 48 명으로 향후 충분한 수의 환자군을 대상 으로 추가적인 연구가 진행되어야 할 것으로 생각된다.

우리는 임상적으로 협부 갑상선 유두상암이 의심될 경우 조직학적으로 양측 중심 경부 림프절 전이율이 높기 때문에 완전한 양측 중심 경부 림프절 청소술을 시행할 것을 제안한 다. 협부 내에서의 위치에 따른 전이 유무의 차이는 본 연구 에서는 명확히 설명할 수 있는 근거를 밝히지 못했다. 협부에 종양이 위치할 경우 후두전 림프절, 기관전 림프절 및 기관주 위 림프절로의 전이에 강력한 위험인자가 되며, 림프절 전이 는 또 다른 림프절 전이로의 가능성을 높이고 양측 림프절에 서의 전이가 빈번하게 관찰되는 점은 수술적 치료를 고려할 때 양측 중심 경부 림프절 청소술을 고려해야 하는 근거가 된 
다. 비록 현재 예방적 중심 경부 청소술에 대해서는 논란이 있으며 본 연구가 장기간 추적 결과를 보여주지는 못했지만 중심 경부 림프절에서 수술 전 전이 소견이 없었던 협부 갑상 선암 38 case 중 $28 \mathrm{case}(73.7 \%)$ 에서 최종 조직검사 결과상 전 이가 확인이 되었다는 점에서 예방적 중심 경부 청소술은 고려 되어야 한다. 협부 갑상선 유두상암에서 예방적 중심 경부 청소술의 정확한 역할을 확립하기 위해서는 장기간 추적관찰 이 필요할 것으로 생각된다.

협부와 비협부에서 외측 림프절 전이 비율은 비슷하였다 (6.3\% vs. 8.5\%; $p=0.764)$. 협부 갑상선 유두상암에서의 외측 림프절 전이 비율은 다른 문헌에서와 유사하였다. ${ }^{19)}$ 외측 경부 절제술은 영상검사 및 세침흡인세포검사로 확인된 상태에서 비협부 갑상선 종양에서와 같은 전략으로 시행할 수 있었다. 이번 연구의 한계는 후향적인 연구라는 점, 무작위 표본검 출이 아니라는 점, 장기추적검사 자료가 없다는 점이다. 앞으 로 장기추적관찰을 포함한 무작위 대조군 연구가 필요하다. 또한 협부 내에서 림프절 전이에 관련된 다른 인자를 찾고 협 부 종양 위치의 세부적인 기준점에 대한 연구도 좀 더 진행되 어야 할 것이다.

\section{REFERENCES}

1) Noguchi S, Noguchi A, Murakami N. Papillary carcinoma of the thyroid. I. Developing pattern of metastasis. Cancer 1970;26(5): 1053-60.

2) Chai YJ, Kim SJ, Choi JY, Koo DH, Lee KE, Youn YK. Papillary thyroid carcinoma located in the isthmus or upper third is associated with delphian lymph node metastasis. World J Surg 2014;38(6): 1306-11.

3) Ito Y, Kudo T, Kobayashi K, Miya A, Ichihara K, Miyauchi A. Prognostic factors for recurrence of papillary thyroid carcinoma in the lymph nodes, lung, and bone: analysis of 5,768 patients with average 10-year follow-up. World J Surg 2012;36(6):1274-8.

4) Lundgren CI, Hall P, Dickman PW, Zedenius J. Clinically significant prognostic factors for differentiated thyroid carcinoma: a populationbased, nested case-control study. Cancer 2006;106(3):524-31.

5) Sakorafas GH, Sampanis D, Safioleas M. Cervical lymph node dissection in papillary thyroid cancer: current trends, persisting controversies, and unclarified uncertainties. Surg Oncol 2010;19(2): e57-70.

6) Mazzaferri EL, Doherty GM, Steward DL. The pros and cons of prophylactic central compartment lymph node dissection for papillary thyroid carcinoma. Thyroid 2009;19(7):683-9.

7) Ji YB, Lee DW, Song CM, Kim KR, Park CW, Tae K. Accuracy of intraoperative determination of central node metastasis by the surgeon in papillary thyroid carcinoma. Otolaryngol Head Neck Surg 2014;150(4):542-7.

8) Conzo G, Tartaglia E, Avenia N, Calò PG, de Bellis A, Esposito K, et al. Role of prophylactic central compartment lymph node dissection in clinically N0 differentiated thyroid cancer patients: analysis of risk factors and review of modern trends. World J Surg Oncol 2016; 14:149.

9) Lee KE, Chung IY, Kang E, Koo DH, Kim KH, Kim SW, et al. Ipsilateral and contralateral central lymph node metastasis in papillary thyroid cancer: patterns and predictive factors of nodal metastasis. Head Neck 2013;35(5):672-6.

10) Machens A, Holzhausen HJ, Dralle H. Skip metastases in thyroid cancer leaping the central lymph node compartment. Arch Surg 2004;139(1):43-5.

11) Sadowski BM, Snyder SK, Lairmore TC. Routine bilateral central lymph node clearance for papillary thyroid cancer. Surgery 2009; 146(4):696-703; discussion 703-5.

12) Chisholm EJ, Kulinskaya E, Tolley NS. Systematic review and meta-analysis of the adverse effects of thyroidectomy combined with central neck dissection as compared with thyroidectomy alone. Laryngoscope 2009;119(6):1135-9.

13) White ML, Gauger PG, Doherty GM. Central lymph node dissection in differentiated thyroid cancer. World J Surg 2007;31(5):895-904.

14) Song CM, Lee DW, Ji YB, Jeong JH, Park JH, Tae K. Frequency and pattern of central lymph node metastasis in papillary carcinoma of the thyroid isthmus. Head Neck 2016;38 Suppl 1:E412-6.

15) Cranshaw IM, Carnaille B. Micrometastases in thyroid cancer. An important finding? Surg Oncol 2008;17(3):253-8.

16) Rosenbaum MA, McHenry CR. Central neck dissection for papillary thyroid cancer. Arch Otolaryngol Head Neck Surg 2009;135(11): 1092-7.

17) Haugen BR, Alexander EK, Bible KC, Doherty GM, Mandel SJ, Nikiforov YE, et al. 2015 American Thyroid Association Management Guidelines for adult patients with thyroid nodules and differentiated thyroid cancer: the American Thyroid Association Guidelines Task Force on thyroid nodules and differentiated thyroid cancer. Thyroid 2016;26(1):1-133.

18) Ito $Y$, Higashiyama $T$, Takamura $Y$, Miya A, Kobayashi K, Matsuzuka $\mathrm{F}$, et al. Risk factors for recurrence to the lymph node in papillary thyroid carcinoma patients without preoperatively detectable lateral node metastasis: validity of prophylactic modified radical neck dissection. World J Surg 2007;31(11):2085-91.

19) Lee YS, Jeong JJ, Nam KH, Chung WY, Chang HS, Park CS. Papillary carcinoma located in the thyroid isthmus. World J Surg 2010;34(1): 36-9.

20) Goldfarb M, Rodgers SS, Lew JI. Appropriate surgical procedure for dominant thyroid nodules of the isthmus $1 \mathrm{~cm}$ or larger. Arch Surg 2012;147(9):881-4.

21) Sugenoya A, Shingu K, Kobayashi S, Masuda H, Takahashi S, Shimizu T, et al. Surgical strategies for differentiated carcinoma of the thyroid isthmus. Head Neck 1993;15(2):158-60.

22) Hahn SY, Han BK, Ko EY, Shin JH, Ko ES. Ultrasound findings of papillary thyroid carcinoma originating in the isthmus: comparison with lobe-originating papillary thyroid carcinoma. AJR Am J Roentgenol 2014;203(3):637-42.

23) Iyer NG, Shaha AR. Management of thyroid nodules and surgery for differentiated thyroid cancer. Clin Oncol (R Coll Radiol) 2010;22(6): 405-12.

24) Cooper DS, Doherty GM, Haugen BR, Kloos RT, Lee SL, Mandel SJ, et al. Management guidelines for patients with thyroid nodules and differentiated thyroid cancer. Thyroid 2006;16(2):109-42.

25) Dackiw AP, Zeiger M. Extent of surgery for differentiated thyroid cancer. Surg Clin North Am 2004;84(3):817-32.

26) Watkinson JC; British Thyroid Association. The British Thyroid Association guidelines for the management of thyroid cancer in adults. Nucl Med Commun 2004;25(9):897-900.

27) Ranade AV, Rai R, Pai MM, Nayak SR, Prakash, Krisnamurthy A, et al. Anatomical variations of the thyroid gland: possible surgical implications. Singapore Med J 2008;49(10):831-4.

28) Ozgur Z, Celik S, Govsa F, Ozgur T. Anatomical and surgical aspects of the lobes of the thyroid glands. Eur Arch Otorhinolaryngol 2011; 268(9):1357-63.

29) Dixit D, Shilpa MB, Harsh MP, Ravishankar MV. Agenesis of isthmus of thyroid gland in adult human cadavers: a case series. Cases J 2009; 
2:6640.

30) Won HS, Chung IH. Morphologic variations of the thyroid gland in Korean adults. Korean J Phys Anthropol 2002;15(2):119-25.

31) Won HS, Han SH, Oh CS, Chung IH, Won HJ, Kim JH. Location and morphometry of the thyroid isthmus in adult Korean cadavers. Anat Sci Int 2013;88(4):212-6.
32) Hoyes AD, Kershaw DR. Anatomy and development of the thyroid gland. Ear Nose Throat J 1985;64(7):318-33.

33) DeLong ER, DeLong DM, Clarke-Pearson DL. Comparing the areas under two or more correlated receiver operating characteristic curves: a nonparametric approach. Biometrics 1988;44(3):837-45. 